\title{
米國生れ二世の體位と日本人との比較
}

\author{
不原 房雄
}

二世の研究は日本民族が、其榮養や環境衞生改善に依つて、ぞれだけ優良化し得るかを見 るのに最も意義深い研究である。二世の研究は、私が 1930 年渡米の際成人 253 名に初交 り、私の指導で須々木榮氏がロスアンヂルス市で小中學學徒 2583 名の調査あり、次いで伊 藤久治氏の 202 名の新生兒と女子 267 名の研究あり、1951 年飯高葴子氏の米進駐軍中の二 世 258 名の研究があり、共に其都度日本人の體位と比較發表したが、これらと別に 1939 年 Oxford 大學 SirAPIRO 教授のハワイの二世の調査もあり、これらを併せ總括して茲に記 述したい。

身長：生れた時已に二世は日本人より 2.2 糎大きく、學音の折は $9-7$ 㮒づ〉大きく、成 人ではロスアンヂルス市の 169.5 朄で最も大きく、日本人に比し 9.5 糎 $(4.8 \%)$ 大きい。米國 內でも他の州の人はそれ程ではなく、ハワイの二世は最も小さく 165 粴である。ハワイは畳 もあり米食味噌汁で純米式ではない。又發青途中數年を日本國內で育つたという人は必ず 3 緾位低くなつていた。

今。其身長の年々の發青曲線を見ると、二世的人と全く同じ發育を逐げているが、それ も 15 才までぶ、15 才から 20 才までは白人は佾 12.8 糎も伸びるが、二世は 9.5 糎しか伸

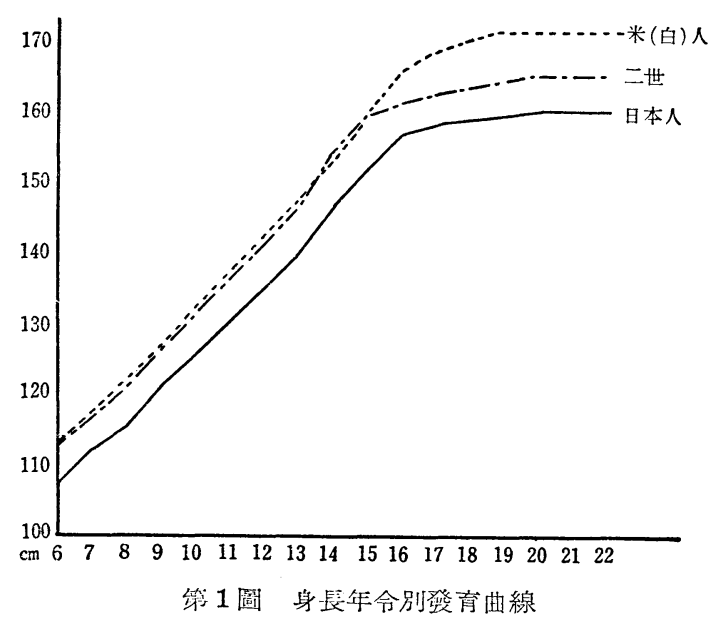
びないし、日本人は 7.3 種しか伸びな いのである。これは恐らく人種の差で あろ5(第 1 圖)。米國以外の地で成育 した二世を調べたが、常に日本人より 劣つて $2-6$ 榞小さく、南洋諸島最も 惡く、臺灣、樺太これに繼ざ、滿洲は 最も良かつた。

體重、皮厚、上膊圍： 3 者共に榮養 指數の基準となるもので、共に二世は 著しい優秀を示していた。體重は 8.9 瓦 (17\%) 重く、皮厚は 15.6粍で、日本 人の 7.0 糎に皎べ 2 倍以上で獨人と同 じ數字である。上膊圍は 27.8 糎で日 本人本均より $13.5 \%$ 大きく、榮湌の優秀さと同時に筋肉の鍛鏀を物語るものである。二廿 にスポーツはと聞くと必ず 2,3 種を嗜んでいた。

下肢長、坐高: 下肢長は二世は 8.3 㱫、女子は 2.7 㮒長く、比下肢長も地方地方により差 はあるが 1.0-2.7\% 大きく、最高 $53.7 \%$ というと恰度獨人の比下肢長の數字に一致してい る。反之比坐高は $2.3 \%$ 低くなつていて、大體比下肢長が延びているその割合に比坐高が縮 んでいるのを見た。 
そこで坐高と下肢長との關係を實數で見るために、二世で日本人位の本均身長（160 粝） の人 47 名を選び、其下肢長と坐高に就て日本人と比較して見ると、下肢長は 0.9 種伸びて いたが、坐高は 1.1 絰縮んで短くなつていたのを見た。そこで新生兒ではどうかと調べてみ ると、日本人と二世とでその差はなかつたのである。では何才から坐高が短くなるのかを見 るために、新生兒から成人までの比坐高と比下肢長の發育曲線を描いて見た。只殘念なこと には二世の下肢長を測つたもので、1才から6才までのものが缺けていた。それで止むなく 米國で屢々用いる身長から坐高を养引いたものを脚長として、其比脚長を求め、マルチン式 の比下肢長と比較して見たが、其曲線の推移の具合は全く同じであつたので、これを用いた のが第 2 圖である。そして日本人と二世と白（露）人との曲線を見た。そうすると二世と日

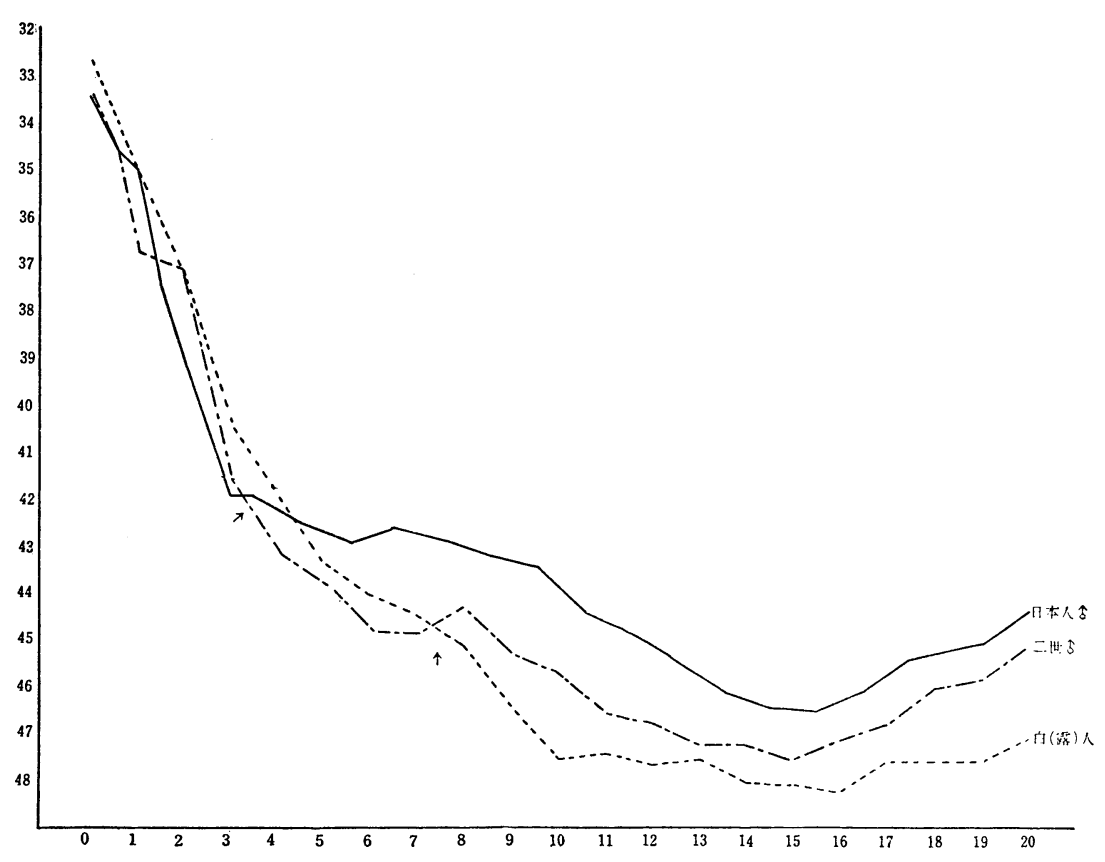

第 2 圖 比脚長の年令的推移曲線の人種別比較

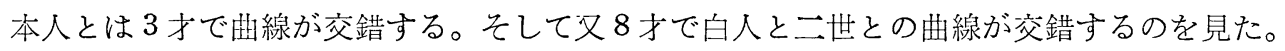
郎ち日本人と二世は 3 才までは全く同じに伸びるが、3才から日本人は比脚長が短くなりズ ット伸び方が惡いのである。そして 8 才で 1.5\%の差で、それから 15 才まで同じで、後成 人までは $1 \%$ 位な差であるが、曲線の歩みは本行している。それで今少し年令的伸長の割合 を究明するために、後述するように、脚長の伸長率を見たのである。又この 8 才で白人と二 世の幽線が交錯している。二世も日本人もそろであるが、8才で伸長率が著しく惡いために、 曲線が殆えぞ水本であるために、白人の曲線と交錯しているのである。これは恐らく人種的 特徵と思う。そして8才から先は大體本行しているが、17才以上で又白人の方が稍々伸びて いる。以上は比脚長であるが、比坐高飞就て見ても大體同じ形であつて、日本人と二世とは 3 才の所で交錯し、8才まで其差が著しいこと比脚長と同じであつた。白人と二世とは交錯 することはなく生涯略々本行して進しでいたが、茲には表を略した。 
依つて脚の伸長を年令別に確めるために、其伸長率を人種別に比較して見た。郎ち其年令 の初めの脚長に對し、1ケ年間に伸びた長さの比率を曲線に示したのである。第 3 圖がそれ で二世と日本人とは其伸長率 3 才までは全く同じであるが、4才で二世は白人と同じく 10.7 \%であるのに、日本人は $4.7 \%$ で牛分たらずである。そして 5 才で二世と白人は $9 \%$ である

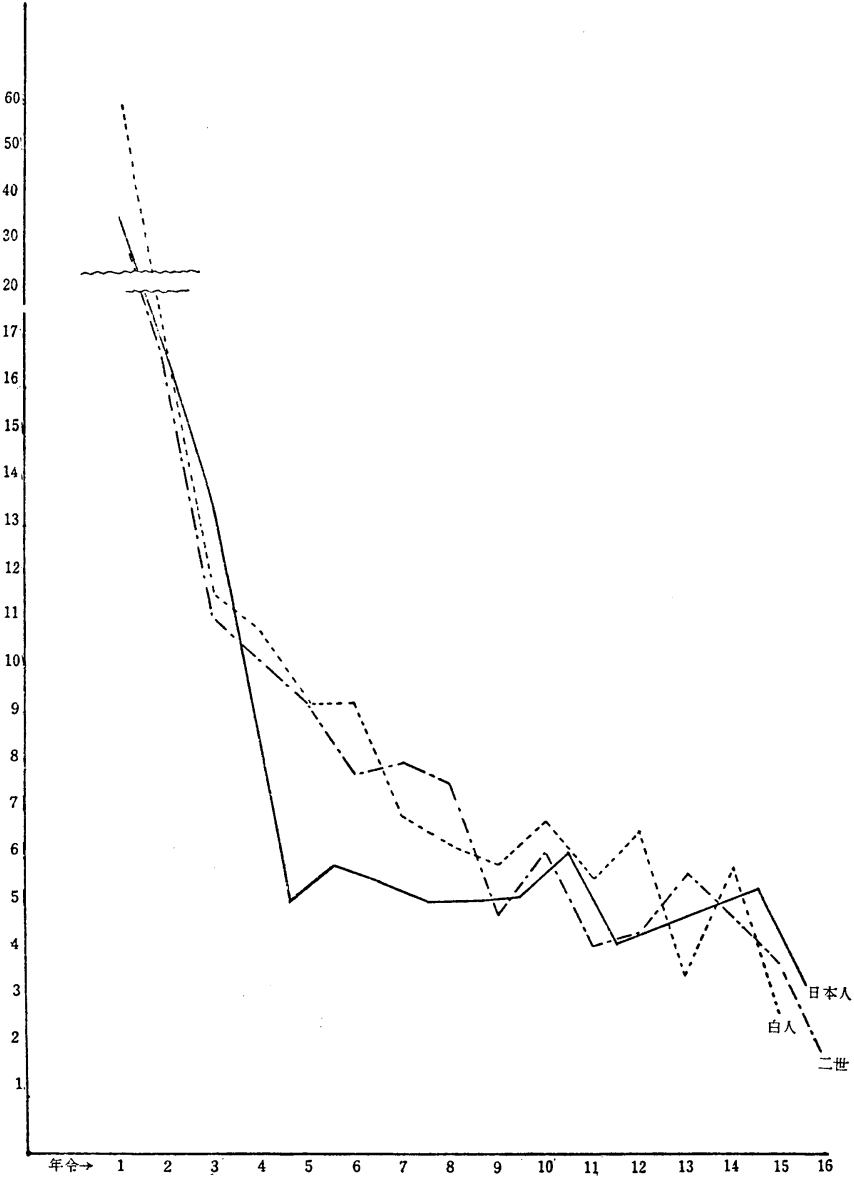

第 3 圖 比脚長の年令別伸長率の比較 のに、日本人は $5.5 \%$ であ る、6,7,8 才と段々に其差 は小さくなり、9才からさ きは 3 者共に同じ制合に神 びていたのである。白人と 二世とは常に同じ曲線を描 いたが、只新生兒から 1 才。 2 才までの伸長率が、白人 は著しく高く1才までに $66 \%$ を示し、日本人と二世 は共に33\%である。これは 人種的の差で、後述するよ ろに、白人は生れたては下 肢長は短いが急に伸びるも のであると思われる。

依之見ると日本民族は胴 が長くて脚が短いのを特徵 とされているが、天賦の體 質はそうでないということ が判つた。そしてその脚の 伸びの惡いのは 3 才から 8 才までの間に出來上るもの なのである。それなら何故 にこの年でそうなるのか、 頭骨の示數も幼兒は著しく 變るが、6,7才からは一定 する。恐らく脚の骨の恰好もこんな年で一定するものと思われる。依つて之を見るとこの年 頃で脚の伸長を妨げないように、榮養とか體育とかを注意することが大切なことである。只 こっで注意しなければならないことは、二世は脚が長く胴が短いというとの脚の長いという ことは榮養で說明がつこうが、胴の短いということは榮養では說明はつかない。生物は一方 に發青を抑制されると、反對の方に余分に發育するということは屡々見當る現象である。こ の場合も脚の伸長を抑制するものがあつて、それだけ胴が伸びたのではあるまいか。「坐る」 そか「オンブ」することなどが、脚の伸長を抑制したのであるまいか。そうだとすると 3 才 から 8 才まで、特に 3,4 才の時の脚の伸びを抑制しないよう、否これを促進するように心が けることである。ベビー體操など推賞したい所以でもある。勿論骨の發育に大切なビタミン 
「カルンューム」等の榮養をより充分にすることは大切である。

榮養: そこで 10 才前後の二世 275 名の食飭を調べて見ると總カロリー 3061 で、日本人 成人より多く、從つて脂肪 84.7 瓦、カルシニーム 1.03 瓦、 $\mathrm{B}_{2} 2.75 \mathrm{mg}$. は皆日本人の 3 倍 である。寄生虫、小兒傳染病の少ないこと、公衆衛生の完備は共に二世の發育優秀な原因を なしているものであろう。

上肢長：日本人の上肢長は白人に比し短いが、二世は日本人よりも短く、比上肢長で $0.35 \%$ 小さく、又日本人と同じ身長の二世の本均も 1.0 糎短くなつている。二世は又坐高が短くな つている。そこで上肢長/坐高＝指數を求めて見ると二世も日本人も全く同じであるのを見 ると、上肢長は坐高に比例して發肓するものと思われる。

肢間指數 (上肢長/下肢長)：胎兒は上肢長が下肢長より長く、手長猿は生涯そうである。 黑人は下肢長も長いが上肢長殊に前膊が長い。白人は生れたては上肢長が下肢長より長いが 3 才で下肢長の方が長くなる。日本人は生れたてから上肢長より下肢長が長い。白人は 1 才。 2 才で非常な速度で伸びること上述の通りである。

頭指數：頭長は日本人も二世も同じであるが、頭幅が 8 粍大きく、頭指數 85.21 であつた。 ShAPIRO 氏ハワイ人 83.3 (其親一世は 81.0 ) 江口、场田氏等の南洋の二世 84.0 となり。 ブラシル二世も亦 85 になつていて、移民により變るものと思われる。日本解剖學會で大學 生だけの本均 83.8 となり、中澤氏の日大學生は 84.2 となつている。歐洲では文化の進むに つれ長頭型になるというが、日本では短頭になつている。

腦の容皘 : 二世の頭耳高や頭高の测定したものがないので、日本人の頭高 121 粕を用い二 世の頭幅は 159 粍、頭長は 186 籷であつたので、これを用いWELCKER の公式 I で計算す ると 1562 c.c. となり、日本人より 77 c.c. (重量 72 瓦) 大きく、佛人のそれと一致してい る。

鼻型と顏型：二世の鼻高は日本人と同じであるが、鼻巾が小さい。顴骨马幅は同じである が顔高は小さくなり、ために鼻指數、顔指數共に小さくなつていた。江口氏の南洋の二世も 兩者共に小さくなつていた。

月經潮來年令 : 二世は 13 才 1 ケ月（最早 10 才より 18 才）で、日本婦人本均より 1 年 2.8 ケ月も早い。同地白人の 12 才 11 ケ月と僅かに 2 ケの差である。血壓は內地婦人と 差を認めない（收縮時 116.7, 擴張時 68.7 紈)。

知能テスト：米國には各國の人がいるので學校で、作業、知能、性格テスト等の試驗をし て各國人を比較した調查は數々ある。それらを拾つて見ると、電氣的反應速度を高校生に就

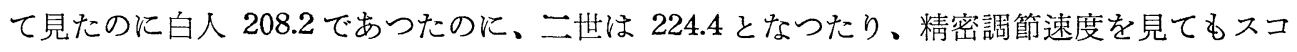
ットランド人 4.6 , 獨人 4.1 , フィリッピン人 3.9 であるのに二世は 4.4 となり、犯罪率を見 ても各國人干人に對し黑人 53.6 , フィリッピン人 12.3 , 米人 8.7 であるのに、二世は僅かに 2.1 であつた。田中寬一博士の知能偏差值を見ても、英人 44.8 , 獨人 43.8 で、二世は 46.3 又二世は日本人に比し著しく外向性であるとなつている。これらは二世の優れたものである が、劣つているものは、GoodenouGH の知能テストでは米人 100.3, 獨人 89.9 であるのに 二世は 99.5となり、背筋力が白人 139.3 互であるのに二世は 118.5 聒である。又 DARsIE 氏の性格テストで、二世は技叮は優れているが、公德心、協調心、獨創力、自己意志乏しく、 自己的であるとしている。台色々の數值は原著に讓つて茲には略したことを了とされたい。 
石原房雄：民族德生 1 绞 5 號。日本醫事新報 1324. 1949.

須々木笑：民族衞坐 16 卷 2 號

伊箱久治: American Journal of Diseases of Children, 1936, Vol. 52. Human Biology, Vol. 14.

No. 3. 1942. 庄族街生 21 兊 1 號

石原房雄、饭高歲子：民族街生 20 卷 1,2 號

江口䉆藏：人類學人類遗傅學體啠學論文集 1 册

塚田腾：同上 4 册、10 册

田中寬一：東京交理科大學文科紀要 $12,14,15,17,19$ 兊

SHAPIRO: Oxford University Press 1939.

Friedenthal: Allgemeine u. spezielle Physiologie d. Menschenwachstum, 1914. Berlin.

STRONG: Stanford University. Press. 1933.

（社會保險中央病院）

\section{A Comparative Study of the Structure of Nisei and of Native Japanese FUSAO ISHIHARA}

An anthropometric examination was conducted of 3563 Niseis, who were born in the United States to parents of pure Japanese stock. As compared with the native Japanese adult, the stature of Nisei is 5 to $9.3 \mathrm{cms}$. greater and the weight 9 to $12 \mathrm{kgs}$. heavier. As shown in Figure 1, the mean growth curve of the Niseis from 6 to 15 years of age is strikingly similar to that of white Americans, but after that age the yearly growth in the case of the latter amounts to $12.8 \mathrm{cms}$. till they become adults whereas in the case of Nisei and Japanese it amounts to only $5.5 \mathrm{cms}$. The second generation Japanese in other countries, such as the Philippines, Sumatra, Korea and Manchuria, do not show such good records of growth, the fiqures falling below those of the native Japanese, by 1 to $4 \mathrm{cms}$. in stature and 5 to $10 \mathrm{kgs}$. in body weight.

On the averge, the leg length of a Nisei is 2.8 to $8.3 \mathrm{cms}$. greater and its ratio to his stature about 1.00 per cent larger than the corresponding figures for a Japanese, and, on the other hand, the sitting height of Nisei is shorter by about 1.2 per cent. It is concluded that leg length of the native Japanese has been shortened, and that their sitting height has increased, as a result of a limitation on growth due to the sedentary habit of daily life.

The biparietal diameter of the head of the Nisei is larger by about $7 \mathrm{mms}$. than that of the Japanese native with no variation in the occipito-frontal diameter. Therefore, the cephalic index work out on the average to 85 for Niseis, as against 81 for Japanese natives. 